\title{
Synthesis of Aryl Ketones by Coupling of Aryl Bromides with an Acyl Equivalent
}

Metal-Mediated Synthesis

Key words

aryl ketones

aryl bromides

acyl anion equivalent<smiles>[R7]C=NNC(C)(C)C</smiles>

\section{$\mathrm{Pd}_{2}(\mathrm{dba})_{3}(2.5 \mathrm{~mol} \%)$, DPEphos (5 mol\%)} NaOt-Bu (1.3 equiv), dioxane, $50-80{ }^{\circ} \mathrm{C}, 24 \mathrm{~h}$<smiles></smiles>
then $\mathrm{H}^{+}, \mathrm{H}_{2} \mathrm{O}$ $\mathrm{R}^{1}=4-\mathrm{OMe}, 4-\mathrm{CN}, 4-\mathrm{CF}_{3}, 4-\mathrm{PhCO}$, etc. $\quad \mathrm{R}^{2}=\mathrm{Alk}, \mathrm{Bn}$<smiles>CCCC(=O)c1ccc(OC)cc1</smiles>

$94 \%$<smiles>CCCC(=O)c1ccc(C(=O)OC(C)(C)C)cc1</smiles>

$70 \%$<smiles>O=C(Cc1ccccc1)C1=CCCCC1</smiles>

$52 \%$<smiles>O=C(c1cccnc1)C1CCCCC1</smiles>

$85 \%$

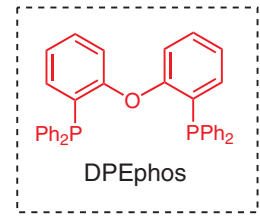

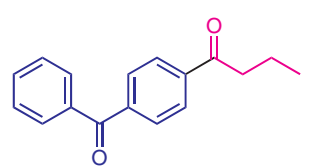

$87 \%$

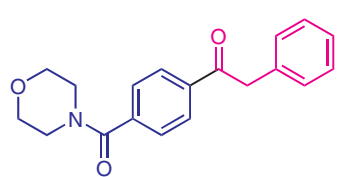

$88 \%$
Significance: The Pd-catalyzed cross-coupling reaction of aryl halides with $\mathrm{C}-\mathrm{H}$ acidic compounds has recently been widely used for the preparation of aryl ketones, esters and amides. Herein, a new elegant method of the synthesis of aryl ketones is reported. It utilizes acyl anion equivalents, readily available from the corresponding aldehydes. This approach avoids the use of strongly nucleophilic organometallic reagents, often incompatible with functional groups in the molecule. The preparation of tert-butylhydrazones from aldehydes is quite simple, and the coupling reaction is highly versatile and easy to perform.
Comment: Hydrazones of aldehydes as acyl anion equivalents were first introduced by J. E. Baldwin (J. E. Baldwin, R. M. Adlington, I. M. Newington J. Chem. Soc., Chem. Comm. 1986, 176178). They were shown to react directly with organic electrophiles (C. W. Alexander, S. Y. Lin, R. K. Dieter J. Organomet. Chem. 1995, 503, 213-220). Their acidity is close to the acidity of an $\alpha$-proton of carbonyl compounds. The addition of an electrophile to those hydrazones gives diazaallyl intermediates. The chemistry of these reagents remains mostly unexplored. On changing the tert-butyl residue of the hydrazone to a phenyl group, its $\mathrm{N}$-arylation proceeds under the same conditions. 